\title{
POTENSI DAN PROSPEK EKONOMIS UDANG MANTIS DI INDONESIA
}

\author{
Iswari Ratna Astuti dan Fitria Ariestyani \\ Pusat Penelitian dan Pengembangan Perikanan Budidaya \\ Jl. Ragunan 20, Pasar Minggu, Jakarta Selatan 12540 \\ E-mail: iswariastuti@yahoo.com
}

\section{ABSTRAK}

Udang mantis merupakan salah satu komoditas hewan laut yang mempunyai nilai ekonomi tinggi. Udang mantis termasuk salah satu jenis krustase laut yang bernilai gizi tinggi, dengan kadar protein dapat mencapai $87,09 \%$. Beberapa spesies udang mantis dikenal sebagai bahan makanan eksotis dan sebagai komoditas ekspor.Jenis-jenis udang mantisyang bernilai ekonomi tinggi adalah dari famili Harpiosquillidae dan Squillidae. Dalam keadaan hidup, udang mantis dijual per ekor berdasarkan ukuran panjang, dengan kisaran Rp 10.000,- hingga Rp 80.000,-. Dalam keadaan mati, udang mantis dijual dengan harga Rp 45.000,- $/ \mathrm{kg}$. Udang mantis dapat hidup dalam air laut maupun air payau, dan sering dijumpai di daerah pesisir maupun pertambakan. Habitat sebagian besar udang mantis adalah pantai, senang hidup di dasar air terutama pasir berlumpur. Udang mantis mempunyai kemampuan beradaptasi yang tinggi, bahkan di daerah yang sudah terkontaminasi. Sampai saat ini udang mantis diperoleh dengan mengandalkan hasil tangkapan nelayan, yang ketersediaannya tergantung musim. Udang mantis merupakan salah satu hasil tangkapan sampingan nelayan dengan target tangkapan utama ikan maupun udang. Dalam rangka mencegah terjadinya penurunan hasil tangkapan sekaligus menjaga kelestarian populasi udang mantis, perlu dilakukan upaya budidaya. Domestikasi sebagai langkah awal dalam usaha budidaya perlu dilakukan, untuk itu, diperlukan penelitian/kajian tentang berbagai aspek seperti aspek biologi, ekologi, reproduksi, genetika, dan lain-lain.

KATA KUNCI : udang mantis, tangkapan sampingan nelayan, domestikasi, krustase laut

\section{PENDAHULUAN}

Indonesia merupakan negara kepulauan yang sangat kaya akan berbagai sumberdaya hayati laut. Keanekaragaman jenis organisme laut banyak dimanfaatkan untuk kesejahteraan masyarakat, terdiri atas ikan, udang, rumput laut, dan kekerangan. Salah satu jenis udang yang berpotensi untuk dijadikan sumber gizi masyarakat namun belum banyak dikenal luas adalah udang mantis.

Udang mantis merupakan salah satu jenis krustase laut yang sangat diminati untuk dikonsumsi, terutama oleh masyarakat mancanegara. Di Indonesia, keberadaan udang mantis sendiri masih belum sepopuler negara tetangga seperti Malaysia. Kandungan gizi udang mantis juga bagus, karena mengandung kadar protein yang tinggi. Menurut Anonim(2010), kadar protein udang mantis mencapai 87,09\%; lebih tinggi dibandingkan jenis udang yang lain. Bahkan konon kabarnya, mengonsumsi udang mantis berkhasiat menambah keperkasaan bagi kaum pria. Khasiat lain dari udang mantis adalah dapat menyembuhkan penyakit buang air kecil yang berkali-kali dan dapat mengobati kebiasaan mengompol pada anak-anak.

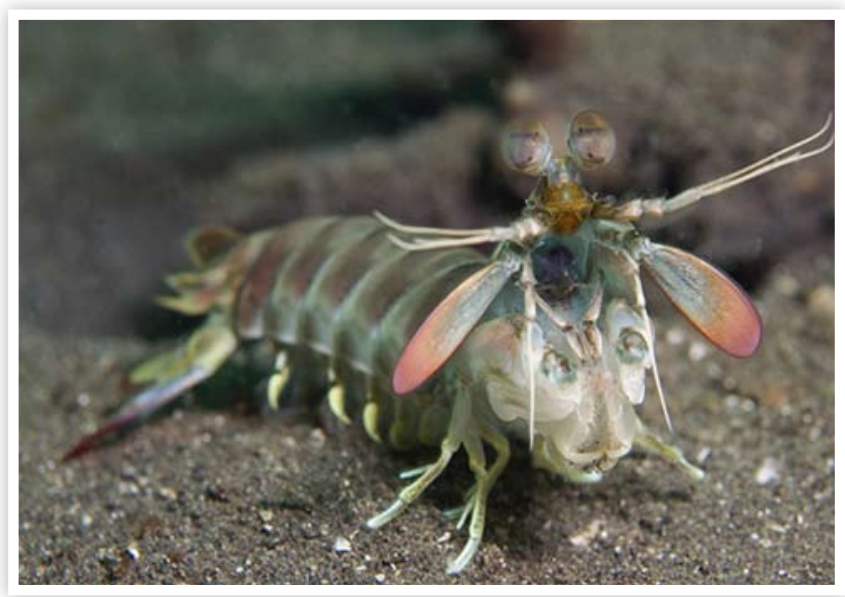

Sumber: http:/www.flickr.com/photos/sharkjames

Gambar 1. Udang mantis (Mantis shrimp) 
Udang mantis merupakan spesies udang laut, termasuk dalam Filum Arthropoda, Subfilum Krustase, Ordo Stomatoda. Terdapat 5 superfamiliyaitu Bathysquilloidea, Gonodactyloidea, Erythrosquilloidea, Lysiosquilloidea, dan Squilloidea, dan terdiri atas 20 famili (Martin, 2001), di mana genus Harpiosquilla (dari famili Squillidae) termasuk stomatoda terbesar, dan Harpiosquilla raphidea (Fabricius) adalah spesies terbesar, yang mencapai total panjang lebih dari $300 \mathrm{~mm}$ (Manning, 1969).

Klasifikasi udang mantis adalah sebagai berikut:

$\begin{array}{ll}\text { Kingdom } & \text { : Animalia } \\ \text { Filum } & \text { : Arthropoda } \\ \text { Subfilum } & \text { : Crustacea } \\ \text { Kelas } & \text { : Malacostraca } \\ \text { Subkelas } & \text { : Hoplocarida (Calman, 1904) } \\ \text { Ordo } & \text { : Stomatopoda (Latreille, 1817) } \\ \text { Subordo } & \text { : Unipeltata }\end{array}$

\section{Deskripsi, Jenis, dan Morfologi}

Udang mantis disebut juga udang lipan, udang getak, udang mentadak, udang eiko, udang ronggeng, dan udang belalang, dalam Bahasa Inggris disebut mantis shrimp atau ada juga yang menyebut dengan praying shrimp. Disebut udang mantis karena penampilan dan karakteristiknya mirip dengan belalang sembah (mantis). Di daerah Serang, Banten, udang ini biasa disebut dengan udang cakrek atau udang plethok, sedangkan di daerah Indera Giri Hilir, Riau, udang mantis disebut dengan nama udang nenek. Di Australia, udang mantis terkenal dengan nama "prawn killers", hal ini karena sifatnya yang agresif terutama pada saat akan menyerang dan membunuh mangsanya. Sepasang capitnya yang kuat dan kokoh sering digunakan untuk menarik perhatian mangsanya, kemudian menyergap dan mengoyaknya. Udang mantis dikenal sebagai hewan yang tahan banting dan mempunyai kemampuan beradaptasi yang tinggi, bahkan di daerah yang sudah terkontaminasi (Gonser, 2003).

Udang mantis mempunyai bentuk badan yang unik karena merupakan kombinasi morfologi dari udang, lobster, dan belalang sembah. Ukuran badan udang mantis bisa mencapai $35 \mathrm{~cm}$ dengan bobot antara 20-200 g/ekor. Hal yang luar biasa pernah dilaporkan bahwa di Hawai pernah ditemukan udang mantis dengan ukuran panjang bisa mencapai $38 \mathrm{~cm}$ (15 inci) (Gonser, 2003). Jenis udang mantis memiliki varietas yang beraneka warna, mulai dari warna gelap, coklat, hingga yang berwarna terang. Beberapa spesies udang mantis memiliki fluoresence atau zat yang membuat badannya terlihat bercahaya dalam kegelapan. Karena bentuknya unik dan warnanya yang indah, beberapa spesies udang mantis sering digunakan sebagai hewan peliharaan di dalam akuarium. Hanya saja, perlu kehatihatian dalam memelihara udang ini di akuarium karena bisa memangsa ikan peliharaan yang lain, dan bisa saja kaca akuarium pecah akibat perilaku udang yang sangat agresif.

Udang mantis termasuk hewan karnivora dan termasuk hewan yang aktif di siang hari (diurnal), malam hari (nokturnal), maupun aktif pada waktu matahari terbenam (crepuscular). Udang mantis merupakan salah satu jenis udang predator yang mampu menyerang mangsa dengan ukuran lima kali lebih besar dari ukuran badannya.

Secara morfologi, udang mantis memiliki garis hitam pada bagian belakang antara antena dan ophthalmic somite, antenula yang menghasilkan zat warna hitam berpusat pada bagian tepi anterior, celah antara torasik somit, serta garis tepi antara anterior dan posterior pada karapas. Karapas hanya menutupi sebagian kepala dan tiga segmen pertama dari toraks. Permukaan badan udang mantis berwarna kekuningan, telson memiliki 6 buah duri kecil, antena sepasang, abdomen terdiri atas 10 ruas, antara satu bagian dengan bagian lain dipisah oleh garis hitam. Uropod bagian dalam dan luar berwarna hitam dan mempunyai bulubulu halus, mempunyai celah torasik dengan tiga bagian propundus yang mempunyai duri-duri kecil yang tajam, telson dipisahkan oleh garis yang berwarna hitam (Anonim, 2012). Mulai dari kepala, kedua sisi badannya, sampai ekor memiliki senjata yang sangat tajam sehingga perlu kehatihatian ketika menangkap jenis udang ini.

Keunikan dari udang mantis adalah mempunyai dua mata yang dapat berputar 360 derajat, berfungsi sebagai radar. Udang mantis juga dikenal mempunyai mata super, karena dapat melihat warna pantulan cahaya ultraviolet hingga inframerah, dapat membedakan kombinasi 11-12 warna primer, dan memiliki kemampuan melihat langsung warna cahaya yang berbeda-beda dari polarisasi cahaya. 


\section{Daerah Penyebaran}

Terdapat sekitar 400 spesies udang mantis yang tersebar di perairan seluruh dunia, terutama di perairan tropis dan subtropis. Di Indonesia, data mengenai spesies, jumlah, dan daerah penyebarannya belum pernah dilaporkan. Namun demikian, terdapat beberapa data mengenai spesies dan asal spesies yang pernah ditemukan, di antaranya Harpiosquilla harpax banyak ditemukan di Pantai Utara Jawa, Selat Malaka sampai ke Laut Pasifik (Ahyong et al., 2008). Di perairan Pemuteran, Bali terdapat empat spesies udang mantis yaitu Haptosquilla glyptocercus, Gonodactylus annularis, Gonodactylus viridis, dan Chrisquilla hystrix (Pujawan, 2012). Spesies Haptosquilla hamifera dan Gonodactyllelus erdmanni terdapat di perairan Sulawesi (Barber \& Erdmann, 2000) (Plaisance et al. dalam Pujawan, 2012), spesies Gonodactyllelus rubiguttatus terdapat di perairan Komodo (Barber \& Erdmann, 2000), dan spesies Gonodactylus chiragra terdapat di Laut Jawa (Porter et al., 2010). Sedangkan di perairan Jambi ditemukan spesies Harpiosquilla harpax, di Cirebon terdapat spesies Harpiosquilla harpax (Dewinta, 2010), Harpiosquilla stephensoni dan Carinosquilla multicarinata, dan di perairan Aceh terdapat spesies Carinosquilla multicarinata (Syafrina et al., 2011). Mashar (2011) meneliti udang mantis asal Kuala Tungkal, Jambi dari spesies Harpiosquilla raphidea dan Oratosquillina gravieri. Di perairan yang sama juga ditemukan spesies Harpiosquilla harpax dan Harpiosquilla raphidea, dengan lebih didominasi oleh spesies Harpiosquilla raphidea (Wardianto, 2009). Di Laut Jawa dan Laut Cina Selatan merupakan daerah penyebaran udang mantis dari famili Harpiosquillidae dan Squillidae (Syafrina et al., 2011).

\section{Habitat}

Udang mantis dapat hidup di air laut maupun air payau, dan sering dijumpai di daerah pesisir maupun pertambakan. Habitat sebagian besar udang mantis adalah pantai, senang hidup di dasar air terutama pasir berlumpur. Di Kalimantan Barat, pada umumnya udang mantis toleran terhadap salinitas antara 14-24 ppt. Jenis udang mantis yang hidup di laut dengan kadar salinitas lebih tinggi biasanya hanya mencapai ukuran 6-12 cm saja (Anonim, 2011). Asstalavista (2012) menyatakan bahwa spesies Harpiosquilla raphidea

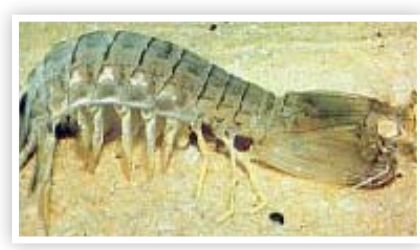

Sumber : http://mangrove.nus.edu.sg (a) Harphiosquilla

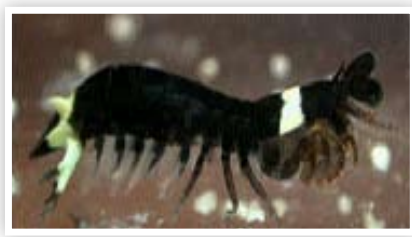

Sumber: http://www.ucmp.berkeley.edu (c) Haptosquilla hamifera

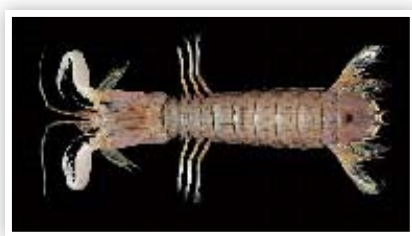

Sumber : http://crust.biota.biodiv.tw (e) Oratosquillina gravieri (Manning, 1978)

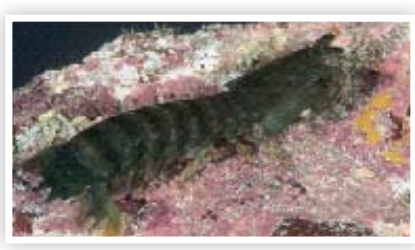

Sumber: http://www.ucmp.berkeley.edu (b) Gonodactylus chiragra

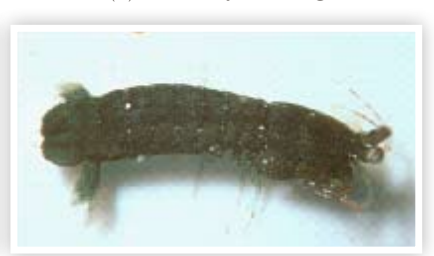

Sumber: http://www.flmnh.ufl.edu (d) Haptosquilla glyptocercus

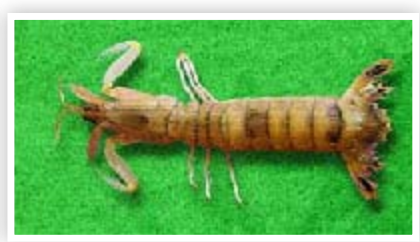

Sumber: http://www.hk-fish.net (f) Carinosquilla multicarinata (White, 1848)
Gambar 2. Jenis-jenis udang mantis yang tertangkap oleh nelayan di Indonesia

hidup di daerah intertidal dengan hamparan berlumpur (mudflat) dengan kedalaman lumpur antara 50-200 cm; salinitas berkisar 12-19 ppt; oksigen terlarut pada kisaran 6,7-7,6 mg/L; pH pada kisaran 7,1-7,8; dan suhu pada kisaran $28,5^{\circ} \mathrm{C}-30,5^{\circ} \mathrm{C}$.

Jenis udang mantis yang lain dilaporkan hidup di antara terumbu karang yang sangat kompleks (Green, 2008), dan memiliki peran penting dalam ekosistem terumbu karang sebagai bioindikator dalam ekosistem laut, yaitu dengan menjaga populasi dan memelihara semua spesies yang ada baik secara langsung maupun tidak langsung. Perilaku hidup dari udang mantis yang menggali lubang pada terumbu karang memberi peluang untuk oksigenasi sehingga kesehatan terumbu karang akan lebih terjaga (Barber et al. dalam Pujawan et al., 2012).

Udang mantis terkenal sebagai spesies monogami yang sangat setia dengan pasangannya hingga 20 tahun dalam masa hidupnya. Dalam seumur hidup, udang mantis mengalami 20 sampai 30 kali pemijahan. Jantan dan betina 


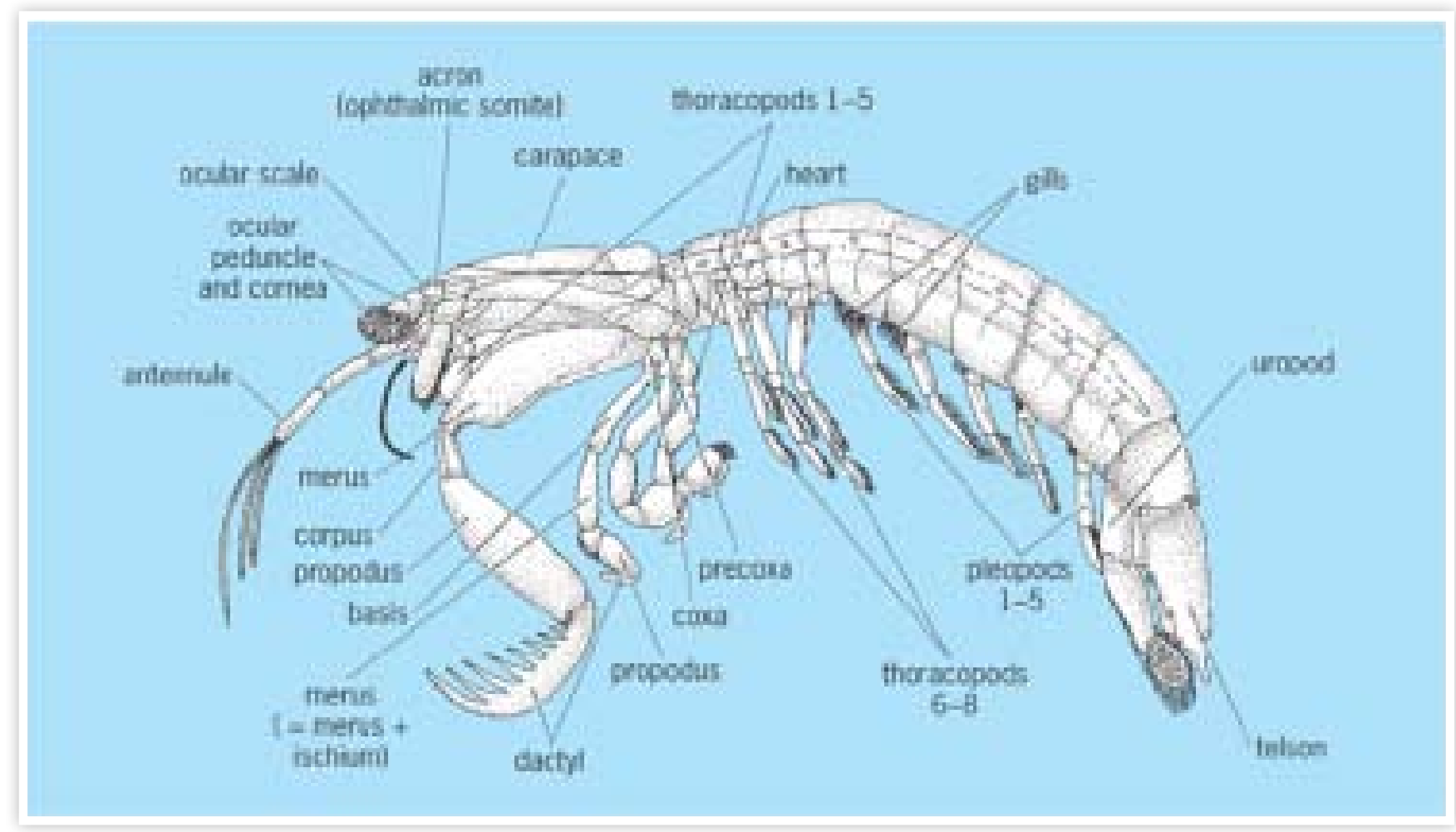

Sumber: $\quad$ Freeman (1980)

Gambar 3. Morfologi udang mantis

bersama-sama hanya pada saat memijah. Setelah terjadi pembuahan, telur diletakkan dan disimpan dalam liang, atau disimpan di bawah ekor betina sampai menetas, tergantung spesiesnya. Setelah telur menetas, larva dapat membutuhkan waktu selama tiga bulan sebagai plankton (Wikipedia, 2012). Choi dalam Dewinta (2010) menyatakan bahwa udang betina mampu bertelur sebanyak 50.000 hingga 1 juta telur, yang akan menetas setelah 24 jam dan menjadi larva nauplius. Tahap perkembangan larva pada udang mantis terdiri atas empat fase. Fase pertama adalah nauplius, larva nauplius tidak dapat berenang sehingga terbawa arus kemana saja arus bergerak, terutama arus yang sejajar garis pantai, bermetamorfosis dalam enam stages berkisar selama dua hari. Fase kedua yaitu protozoea, mempunyai tujuh pasang anggota badan, bermetamorfosis dalam tiga stages berkisar selama tujuh hari. Fase ketiga yaitu mysis bermetamorfosis dalam tiga stages berkisar selama tujuh hari. Fase keempat (terakhir) yaitu postlarva, pada fase ini udang mulai memiliki karakteristik udang dewasa, dilanjutkan menjadi yuwana dan udang dewasa.

\section{Potensi dan Prospek Ekonomi}

Udang mantis merupakan salah satu komoditas hewan laut yang mempunyai nilai ekonomi tinggi. Beberapa spesies udang mantis dikenal sebagai bahan makanan eksotis dan sebagai komoditas ekspor. Jenis-jenis udang mantis yang bernilai ekonomi tinggi adalah dari famili Harpiosquillidae dan Squillidae, di antaranya dari spesies Harpiosquilla harpax, Lysiosquillina maculata, Squilla empusa, dan Squilla mantis (Moosa, 1997).

Bagi masyarakat yang belum pernah melihat udang mantis, biasanya akan merasa aneh untuk mengonsumsi udang tersebut. Meskipun belum banyak dikenal oleh sebagian besar masyarakat Indonesia, namun udang mantis cukup diminati oleh negara-negara Asia seperti Malaysia, Cina, Jepang, Thailand, Filipina, Hongkong, bahkan sangat populer di negara-negara mediterania sampai ke Eropa. Di Jepang, udang mantis merupakan bahan baku untuk membuat masakan sashimi (dalam bahasa Jepang disebut shako). Di Cina udang ini populer sebagai makanan yang cukup mahal, orang Canton menyebutnya dengan"pissing shrimp" (lai niao xia, dalam bahasa Mandarin dan laaih liu ha 
dalam bahasa Canton Modern) (Anonim, 2012). Di Filipina, udang mantis dikenal sebagai tatampal, hipong-dapa atau alupihang-dagat (Wikipedia, 2012).

Udang mantis memiliki harga yang relatif lebih tinggi dibanding jenis udang lainnya. Dalam keadaan hidup, udang mantis dijual per ekor berdasarkan ukuran panjang, dengan kisaran Rp 10.000,-/ekor (ukuran 6 inci) sampai Rp 80.000 ,-/ekor (ukuran 11 inci). Dalam keadaan mati, udang mantis dijual dengan harga Rp 45.000,-/kg (Thahar dalam Intankiswari, 2012).

Meskipun udang mantis belum begitu populer di Jakarta, namun masyarakat di beberapa daerah di Jambi, Kalimantan, Riau, Batam, dan Manado sudah lebih dahulu mengenal udang ini sebagai salah satu menu makanan yang lezat rasanya. Di Jakarta, udang mantis dijual dalam bentuk segar maupun beku, dan saat ini pemasarannya masih terbatas di pasar modern atau supermarket tertentu. Dalam bentuk matang, udang mantis kerap dijumpai sebagai menu eksotis di beberapa rumah makan khusus sea food dengan harga yang lumayan mahal, sampai ratusan ribu rupiah untuk ukuran udang sekitar $200 \mathrm{~g}$. Sedangkan di Manado, beberapa rumah makan di sepanjang Pantai Kalase menyediakan menu udang mantis, satu ons udang mantis yang sudah masak harganya sekitar Rp 27.500,-.

\section{Potensi Budidaya}

Sampai saat ini udang mantis diperoleh dengan mengandalkan hasil tangkapan nelayan, yang ketersediaannya bergantung musim. Udang mantis merupakan salah satu hasil tangkapan sampingan nelayan dengan target tangkapan utama ikan maupun udang.

Berbeda dengan budidaya udang windu dan udang budidaya lainnya, hingga saat ini belum ada kegiatan usaha budidaya udang mantis. Namun demikian, usaha pemeliharaan udang mantis sudah dilakukan, dalam artian memelihara bukan dari hasil pemijahan tetapi memelihara hasil tangkapan dari alam yang ditampung di dalam bak pemeliharaan, baik di KJA maupun di tambak. Pemeliharaan biasanya dilakukan untuk jangka waktu yang berbeda-beda dengan maksud untuk membesarkan udang mantis yang tidak/belum memenuhi ukuran pasar. Pakan yang diberikan adalah ikan rucah yang dipotong besar. Biasanya udang

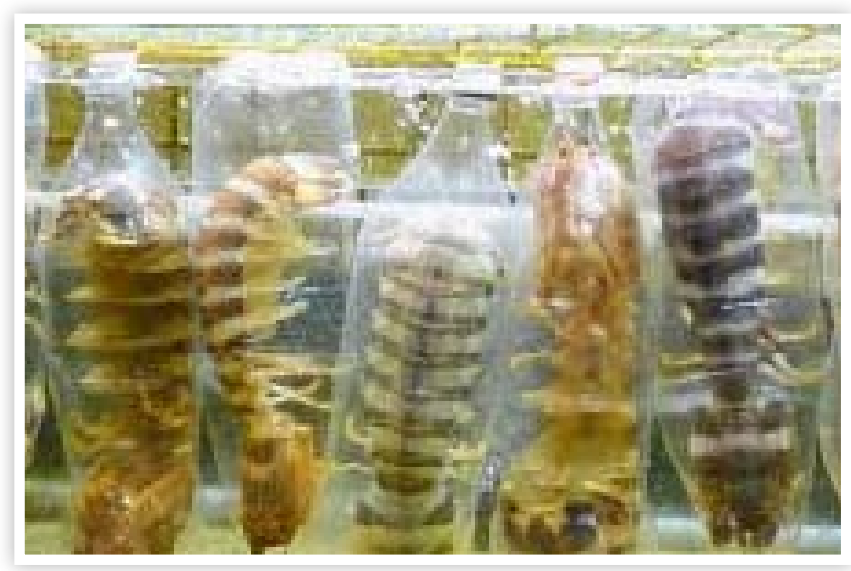

Gambar 4. Udang mantis dipelihara dalam keadaan hidup di dalam botol plastik dalam bak atau wadah akuarium sebelum dipasarkan atau dimasak

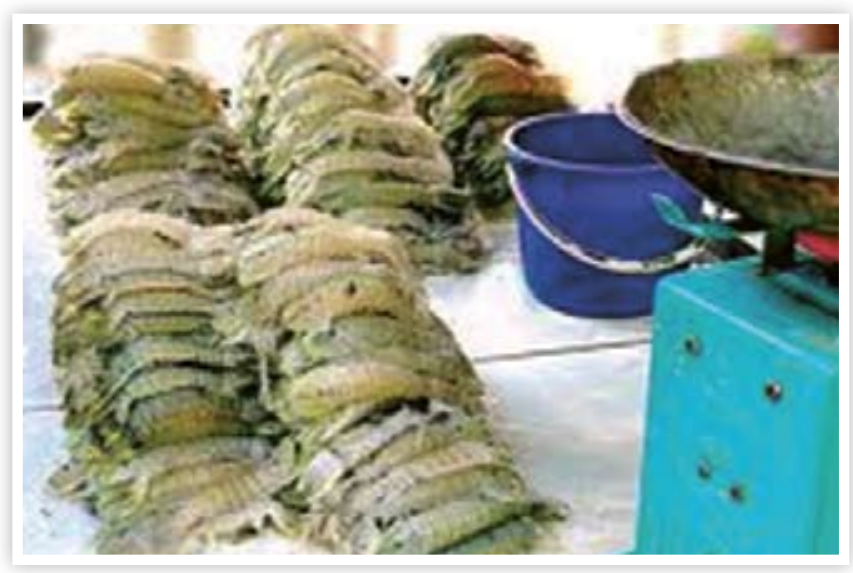

Gambar 5. Contoh penjualan udang mantis segar di Malaysia

mantis akan mendekap pakan yang diberikan dengan kedua capit besarnya, dan memakan pakan yang diberikan sedikit demi sedikit.

Dalam rangka mencegah terjadinya penurunan hasil tangkapan sekaligus menjaga kelestarian populasi udang mantis, perlu dilakukan upaya budidaya. Domestikasi sebagai langkah awal dalam usaha budidaya perlu dilakukan, untuk itu, diperlukan penelitian/kajian tentang berbagai aspek seperti aspek biologi, ekologi, reproduksi, genetika, dan lain-lain.

\section{KESIMPULAN}

Udang mantis merupakan salah satu jenis krustase laut yang bernilai ekonomis, baik sebagai sumber gizi masyarakat maupun sebagai komoditas ekspor. Udang mantis mempunyai kemampuan beradaptasi yang tinggi, 
bahkan di daerah yang sudah terkontaminasi. Sampai saat ini udang mantis diperoleh dengan mengandalkan hasil tangkapan nelayan, yang ketersediaannya bergantung musim. Upaya budidaya perlu dilakukan dalam rangka mencegah terjadinya penurunan hasil tangkapan sekaligus menjaga kelestarian populasi udang mantis. Untuk itu, perlu dilakukan upaya domestikasi sebagai langkah awal dalam usaha budidaya, dan selanjutnya perlu diteliti/dikaji tentang berbagai aspek meliputi aspek biologi, ekologi, reproduksi, genetika, dan lain-lain .

\section{DAFTAR ACUAN}

Ahyong, S.T., Chan T.Y., \& Liao, Y.C. 2008. A catalogue of mantis shrimps (Stomatopoda) of Taiwan. National Taiwan Ocean University: Keelung.

Amarmaziah. 2011. Seri Biologi (1). Tendangan mematikan udang mantis. http://my.opera.com

Anonim. 2010. Perubahan komposisi kimia dan vitamin daging udang ronggeng (Harpiosquilla raphidea) akibat perebusan. http:/NANGKA-TOK.BLOGSPOT.COM

Anonim. 2011. Budidaya udang lipan. http://perikananlaut. wordpress.com

Anonim. 2012. Udang kipas/udang lipan/udang ronggeng/ mantis shrimp. http://info—budidaya.blogspot.com

Anonim. 2012. Udang lipan (Mantis shrimp). http:// zonaikankita.blogspot.com

Barber, P.H. \& Erdmann, M.V. 2000. Molecular systematics of the Gonodactylidae (Stomatopoda) using mitochondrial cytochrome oxidase c (subunit 1) DNA sequence data. J. Crust. Biol. AF205254.1 Gl: 11078499.

Dewinta, Achmad, F., \& Yusli, W. 2010. Pola distribusi geografis pada udang mantis di PantaiJawa berdasarkan genom mitokondria. Departemen Biologi. FMIPA, Institut Pertanian Bogor.

Freeman, W.H. 1980. Comparative morphology of recent crustacea. The McGraw-Hill Companies. San Fransisco.

Gonser, J. 2003. Large shrimp thriving in Ala Wai Canal muck. Honolulu Advertiser. http://ms.wikipedia.org/ wiki/udang_lipan

Hamdani, M. 2010. Data nilai gizi ikan. Balai Besar Penelitian dan Pengembangan Pengolahan Produk dan
Bioteknologi Kelautan dan Perikanan. Badan Litbang Kelautan dan Perikanan. www.bbp4b.litbang.kkp. go.id

Intankiswari. 2012. Perubahan komposisi protein dan asam amino daging udang ronggeng (Harpiosquilla raphidea) akibat perebusan. http://Intankiswari.wordpress.com

Manning, R.B. 1969. A Review og the gebus Harpiosquilla (Crustacea, Stomatoda), with descriptions of three new species. Smithsonian Contributions to Zoology Number 36. Smithsonian Institution Press. City of Washington.

Mashar, A. 2011. Distribusi spasial udang mantis Harpiosquilla raphidea dan Oratosquillina gravieri di Kuala Tungkal, Kabupaten Tanjung Jabung Barat Provinsi Jambi. http://repository.ipb.ac.id

Moosa, M. 1997. Stomatopoda sebagai salah satu potensi sumberdaya hayati laut. Pewarta Oseana, 5: 1-6.

Porter, M.L., Zhang, Y., Desai, S., Caldwell, R.L., \& Cronin, T.W. 2010. Evolution of anatomical and physiological specializations in the compound eyes of stomatopod crustaceans. J. Exp. Biol., 213 pp.

Pujawan, A.G.N.O., Tjok, S.N., \& I Gusti, N.K.M. 2012. Identifikasi spesies udang mantis (Stematoda) di perairan Pemuteran dengan menggunakan gen cytochrome C oxidase subunit-1 dari DNA mitokondria. Indonesia Medicus Veterinus, 1(2): 268-280.

Shafrina \& Raisa, A. 2011. Penggunaan DNA barcode sebagai alternatif identifikasi spesies udang mantis. http://repository.ipb.ac.id

Wardiatno, Y., Farajallah, A., \& Ali, M. 2009. Kajian aspek reproduksi dan genetika udang mantis (Harpiosquilla raphidea, Fabricius 1798) di Kuala Tungkal, Kabupaten Tanjung Jabung Barat, Jambi sebagai upaya lanjutan domestikasi udang mantis. Laporan Penelitian. Lembaga Penelitian dan Pengabdian Kepada Masyarakat. Institut Pertanian Bogor, $36 \mathrm{hlm}$.

Wardiatno, Y., Joko, S., \& Ali, M. 2012. Biochemical composition in two populations of the mantis shrimp, Harpiosquilla raphidea (Fabricius 1798) (Stomatoda, Crustacea). Jurnal Ilmu Kelautan, 17(1): 490-58.

Wikipedia. 2012. Mantis shrimp. http://en.wikipedia.org/ wiki/Mantis_shrimp 